\title{
ABOUT THE ORNAMENTATION IN USE BY SAVAGE TRIBES IN DUTCH GUIANA AND ITS MEANING.
}

BY

\author{
L. C. VAN PANHUYS.
}

Against the term "Savage tribes" the remark was made more then once that it gave generally an inaccurate impression. Such might also be the case here, but the expression was chosen to announce that we would have the deal only with the Indians and the Bush-negroes and not with the more civilized part of the population in the colony of Surinam. Among those Indians we call ine the first place three tribes of "tamed" savages, known in the colony as Arowacks, Caribs and Warauen (Guaranos), living in the coastand savannahregion. There are still other Indians in Surinam, as we know from the voyage of a mixed Dutch-French Commission in 1861 to the upper-Lawa, from the explorations of Crévaux and Coudreau at the same East frontier river, and from informations from Bush-negroes, buth they live in the deep and yet unknowu interior and near to the South frontier Tumucumaque mountains. Between those Indians (Acouris, Trios, Oyacoulés and Rucujanas (Roucouyennes) and the colonist is no communication; it seems that the Bush-negroes have increased the Indians fear for the white man, in order to keep in a state of dependency these Indians to whom they procure iron axes, knives and beads, in exchange for feather-work, hammocks and hunting dogs.

The Bush-negroes, descendants of runaway slaves brought from Africa, have established themselves in several tribes, under chiefs or "Grammans" and with a kind of republican form of "government." They kept many reminiscences from Africa in language and manners, of which several are only partially known. They form in almost every respect, as Professor Joest rightly remarked, the most original, remarkable and interesting people in the present Guyana. 
To prove how little the have been studied, I will state that it was found, only a very few years ago, that their chief tribe, the Aucaners (Djoecas) make use of a "drum-languagen, by which they warn each other, as some peoples in Africa do, in a short time at great distances by means of blows on a drum in a different time and manner. ' This custom had remained unknown, nothwithstanding the daily contact with the colonists.

For the study of these non-civilized tribes of Surinam Mr. Joests "Ethnographisches und Verwandtes aus Guyana", Internationales Archiv für Ethnographie, Supplement zu Band V, 1893, must be mentioned first. I do not know what brought the author to several incorrect impressions and conclusions he gave about the colony, it seems to me that about the colonial "politics", he obtained informations from persons who where not much to be trusted, and that his stay in the colony was too short to correct their tales, but this does not take away the great value of his work for the anthropology of Surinam of the last time. Next to Joest comes Kappler, the patient observer who lived for many years at the Marowyne and wrote "Surinam" u. s. w. (1887); for the early history of the Bush-negroes it will be the best to consult the Description of Guiana or the Wild Coast, etc., by Mr. J. J. Hartsinck. D. C. L. 1770 (Translated titre).

Indian ornaments are to be found: in basket work, on pottery (woman labour), on clubs, arrows and on their own body, especially when going to a dancing-feast. I stated that coast Indians painted ornaments on hammocks made by Bush-negroes, and given to them for the purpose. Farther we have Indian ornaments in "kwejus" (aprons) and feather-work.

As far as my knowledge of Indian ornaments permits I should say that their ornaments have undergone no influence neither from the Bush-negroes, nor from the more civilized. Knowledge of the Indian manner of thought would be the way to understand their ornamentation, and in that part there is still much to be done. But while we know on one part that the Coast Indians have learned the negro-english and when there is some probability that they may have adopted some superstitions from the Bush-negroes, I will point out that these Coast-Indians have clung strongly to their own

1 Catalogue of the Netherland West-India Exposition at the Colonial Museum at Haarlem in 1899, page 76 and 77 . (Translated titre). 
primitive customs. The use of fire weapons, of iron axes and knives, of an iron plate instead of a stone one (for roasting manioc meal), of an iron rasp for grating the manioc root, may be with the use of alcoholic drinks from the white man the principals which they have inherited from the colonists.

About the meaning of Indian ornaments I must refer to the illustrated article in the International Archiv für Ethnographie, 1898 , in which I tried to indicate that the Indian ornament might be chiefly derived from the frog, that amphiby being considered then by the Indian as a human being. The arguments given there will be strengthened by what I found on pag. 144 of the Voyages dans l'Amérique du Sud by $\mathrm{D}^{\mathrm{r}}$ J. Crévaux, Paris, Hachette \& Cie, 1883: "Les dessins de grenouilles que Brown a trouvés dans l'Esse"quibo ne sont d'autres que des images humaines telles que les "Galibis, les Roucouyennes et les Oyampis en représentent journel"lement sur leurs pagaras, leurs poteries ou sur leur peau. Nous "avons cru nous-même, en examinant ces figures aux jambes et aux "bras écartés, qu'il's agissait de grenouilles, mais les Indiens nous "ont tous dit que c'était leur manière de représenter l'homme."

The Bush-negroes carve their ornaments in wood, on doors, boats, paddles, tables, small seats, scuttels, candle-holders, drums, walking sticks, hairpins, and other objects. Needle work ornaments are made by men and women in company; carving gourds and tattooing is female labour, so we meet there with special female ornaments. Influence from the Indians and from the civilized will be observed to a certain degree, but before drawing conclusions I will state how I discovered the meaning of their ornaments.

Several objects (now exposed in the Colonial Museum at Haarlem) were collected at Albina, on the east frontier river of Surinam, where I stayed between 1893 and 1896 and came as functionary of the Government with Bush-negroes nearly in daily contact. I got ornaments there by drawings, later also by rubbing wax on Japanese paper, pressed upon the object (method Hjalmar Stolpe). By and by my litte friends, the bush-negro-children gave names, and, on information, explained the ornaments which they showed me on their toys, and I got more explanation or could correct that of the children by inviting the older ones to see my collection and by noting down their observations.

From the meaning I got in that way from several hundred ornaments, I come to these preliminary conclusions: 
$1^{\circ}$. Each artist has his own individual work and makes his own combinations, yet the ornaments are strongly under the same (tribal) style.

$2^{\circ}$. There is a marked difference between the ornaments of the Aucaners (Djoecas) and those of the Saramaccaners (a tribe living at the Upper-Surinam).

$3^{\circ}$. The ornaments are made by copying animals and objects in the surroundings, and arranging them in the way they think best.

$4{ }^{\circ}$. The eye of the iguana (Lacerta agilis), is the most characteristic ornament by the Aucaners and serves for combinations as for instances for human forms and also for centipedes.

$5^{\circ}$. The masculin sex of human figures is alway pointed out very distinctly. The phallus is sometimes represented by an arrow.

$6^{\circ}$. Snake and bird designs are numerous and are represented in connection with religious ideas. Plants are very rare in representation.

7\%. The tattooing desigus are the most conventional and seem to have been copied from each other.

I think it will be of great interest to continue these researches.

Indeed two explorers have tried to do so. On July $1^{\text {st }}$ of 1903 two military officers started for Surinam, and explored, together with a mine engineer, a doctor, and thirty workmen, the Gonini river. They collected Bush-negro ornaments, also by the Method Stolpe, tried, but alas without success, to note down the meaning of the ornaments and to find competent persons in the colony, willing to continue their work. Perhaps some of these ornaments will be exhibited at the next Congress at Stuttgart. In the month of June of this year (1904) an expedition will start for the Tapanahoni and Upper Surinam, and will perhaps be able to collect there ornaments at the bushnegroes, who live near those rivers. 